\title{
Peningkatan Skala Produksi Mikroenkapsulat Minyak Sawit Merah dengan Pengering Semprot
}

\section{Scale up of Red Palm Oil Microencapsulation Production by Spray Dryer}

\author{
Dede R. Adawiyah ${ }^{1,2) *}$, Leonardus B. Raditya Prabowo'), Purwiyatno Hariyadi ${ }^{1,2)}$ \\ ${ }^{1)}$ Departemen Ilmu dan Teknologi Pangan, Fakultas Teknologi Pertanian, Institut Pertanian Bogor, Bogor \\ ${ }^{2}$ South East Asian Food and Agricultural Science and Technology Center, Institut Pertanian Bogor, Bogor

\begin{abstract}
Red palm oil (RPO) contains high carotene which can be used as coloring agent and source of provitamin A. Drying technology by means of spray dryer is used in order to concomitantly reduce moisture content of RPO microencapsulates and maintain its carotene content. The objective of this research was to study the scale-up process of the RPO microencapsulate production from laboratory scale ( $8.3 \mathrm{~mL} / \mathrm{min})$ to pilot plant scale (300 mL/min). At laboratory scale, using Buchi 190 spray dryer, the optimum formulation of (Maltodextrin:Gum Arabic) : RPO was (35:15) : 40 or 0.8 parts of RPO compared to one part of microencapsulate coating. At pilot-scale (i.e., $300 \mathrm{~mL} /$ minute), the optimum formulation from lab-scale could not be considered as the optimum one based on carotene content as main parameter. At constant parameter inlet temperature of $215^{\circ} \mathrm{C}$, outlet temperature of $110^{\circ} \mathrm{C}$, pump pressure of $4.5 \mathrm{bar}$, cyclon speed of $2500 \mathrm{~m}^{3} / \mathrm{hour}$, and flow rate of $300 \mathrm{~mL} /$ minute, the best microencapsulates could be produced at ratios of coating agent and RPO ranging from 1:0.3-1:0.6. At pilot scale, flow rate and droplet size were the most important factors in order to produce the dry microencapsulates.
\end{abstract}

Keywords: formulation, microencapsulate, red palm oil (RPO), scale up, spray dryer

\begin{abstract}
Abstrak. Minyak sawit merah mengandung total karoten tinggi yang dapat digunakan sebagai pewarna dan sumber provitamin A. Upaya untuk mempertahankan kandungan provitamin A adalah dengan proses mikroenkapsulasi menggunakan spray drying atau pengering semprot. Penelitian ini bertujuan untuk melakukan kajian peningkatan skala produksi mikroenkapsulat minyak sawit merah dengan pengering semprot dari skala laboratorium $(8.3 \mathrm{~mL} / \mathrm{min})$ ke skala pilot plant $(300 \mathrm{~mL} / \mathrm{menit})$. Proses pembuatan mikroenkapsulat minyak sawit merah (MMSM) dilakukan dengan melakukan formulasi menggunakan pengering semprot skala laboratorium Buchi 190 mini spray dryer menghasilkan formula terbaik dengan perbandingan (Maltodekstrin:Gum Arab) : Minyak sawit merah $=(35: 15): 40$ atau 1 bagian penyalut terhadap 0.8 bagian minyak sawit merah berdasarkan parameter utama total karoten. Peningkatan skala dilakukan dengan menggunakan pengering semprot skala pilot plant. Hasil penelitian menunjukkan formula terbaik dengan pengering semprot skala laboratorium harus disesuaikan kembali untuk memproduksi MMSM dengan pengering semprot skala pilot plant. Penyesuaian formulasi dilakukan dengan merubah komposisi formulasi. Pada parameter suhu inlet $215^{\circ} \mathrm{C}$, suhu outlet $110^{\circ} \mathrm{C}$, tekanan pompa 4.5 bar, kecepatan cyclon $2500 \mathrm{~m}^{3} / \mathrm{jam}$ dan laju alir $300 \mathrm{~mL} / \mathrm{menit}$, dapat diproduksi MMSM pada range perbandingan penyalut dan MSM adalah 1:0.3 hingga 1:0.6. Ukuran droplet yang dipengaruhi oleh laju alir produk dan jenis atomizer menjadi faktor penentu keberhasilan dalam memproduksi MMSM ini.
\end{abstract}

Kata Kunci: formulasi, mikroenkapsulat, minyak sawit merah, pengering semprot, peningkatan skala

Aplikasi Praktis: Penelitian ini memberikan informasi terkait parameter proses mikroenkapsulasi minyak
sawit merah yang perlu dikontrol pada saat melakukan peningkatan skala produksi dari skala laboratorium
ke skala pilot plant menggunakan alat pengering semprot.

\section{PENDAHULUAN}

Minyak sawit merah atau red palm oil (RPO) merupakan hasil olahan dari crude palm oil (CPO) tanpa melalui proses bleaching sehingga masih mengandung karotenoid yang terdiri dari sekitar 60-65\% $\beta$-karoten, 30$35 \% \alpha$-karoten dan 5-10\% karotenoid esensial lainnya (Hama dan Ohbu 2002). Menurut Ditjenbun (2014), produksi CPO Indonesia mencapai 33,229,381 ton pada tahun 2016 dan mencapai angka estimasi 35,359,384 ton pada tahun 2017. Hal ini menjadikan minyak sawit merah adalah komoditi yang cukup melimpah di Indonesia.

Warna merah yang disebabkan kandungan karoten yang tinggi setara 60,000 IU aktivitas vitamin A (Sumarna 2006) pada minyak ini dinilai dapat dimanfaatkan sebagai pewarna alami sekaligus sumber provitamin A melalui mikroenkapsulasi. Pada dasarnya proses mikroenkapsulasi merupakan penyalutan bahan inti 
dengan bahan penyalut. Proses mikroenkapsulasi merupakan proses tepat mempertahankan aktivitas provitamin A karena pada proses ini minyak sawit merah hanya terpapar panas dalam waktu relatif singkat. Penelitian Fasikhatun (2010) membuat mikroenkapsulat minyak sawit merah (MMSM) menggunakan penyalut maltodekstrin dan gum arab. Maltodekstrin digunakan karena dapat melindungi zat inti saat penyimpanan, kelarutan tinggi pada air dingin, membentuk film, memberikan efek penghambatan kristalisasi (Srihari et al. 2010), dan harga relatif murah. Gum arab untuk mendapatkan kestabilan emulsi sebagai hidrokoloid. Potensi MMSM, selain mengandung karoten, juga sebagai pewarna alami mulai dilirik sebagai peluang oleh pihak industri. Penelitian ini dilakukan reformulasi hasil mikroenkapsulasi penelitian Fasikhatun (2010) menggunakan pengering semprot skala laboratorium. Menurut Scoot et al. (2007) peningkatan skala produksi dapat menyebabkan berbedaan kualitas produk sebelumnya yang diproduksi pada skala kecil sehingga diperlukan uji coba untuk produksi skala pilot plant, termasuk reformulasi dari skala laboratorium. Pengering semprot dipilih karena dinilai paling ekonomis untuk produksi besar. Selain sebagai pewarna, MMSM juga memiliki nilai fungsional karena tinggi provitamin A dalam bentuk karoten dan sebagai antioksidan.

Penelitian ini bertujuan mempelajari dan mengonfirmasi parameter formulasi dan proses produksi mikroenkapsulat minyak sawit merah menggunakan pengering semprot dari skala laboratorium $(8.3 \mathrm{~mL} / \mathrm{min})$ ke skala pilot plant $(300 \mathrm{~mL} / \mathrm{menit})$.

\section{BAHAN DAN METODE}

\section{Bahan dan alat}

Bahan utama yang digunakan adalah minyak sawit merah (MSM) dari SEAFAST Center IPB, maltodekstrin DE 10-15, dan gum Arab. Bahan kimia yang digunakan adalah heksana, etanol, $\mathrm{CH}_{3} \mathrm{COOH}$, metanol, $\mathrm{NaCl}$, chloroform, $\mathrm{H}_{2} \mathrm{SO}_{4}$ pekat, dan $\mathrm{NaCl}$. Alat yang digunakan antara lain pengering semprot (BUCHI 190 Mini Spray Dryer), Homogenizer High Shear Rotary Silverson LAR, pengering semprot skala pilot plant $(300 \mathrm{~mL} / \mathrm{menit})$, hot plate, termometer, desikator, neraca analitik, spektrofotometer, stirrer, centrifuge, saringan, autoclave, oven, labu lemak, kertas saring, destilator, penyaring vakum, dan Chromameter CR-200.

\section{Metode penelitian}

Penelitian ini dilakukan dalam tiga tahap yaitu tahap analisis bahan baku minyak sawit merah (MSM), tahap reformulasi, tahap pembuatan mikroenkapsulat dengan menggunakan pengering semprot skala laboratorium, dan produksi skala pilot plant dengan pengering semprot.

\section{Analisis bahan baku MSM}

Tahap analisis MSM meliputi analisis kadar air dengan metode hot plate (AOCS Ca 2b-38 1989), total karoten menggunakan metode spektrofotometri (PORIM p26 1988), analisis bilangan peroksida (AOCS Cd 8-53 2003), dan asam lemak bebas (AOCS Ca 5a-40 1997). Total karoten dijadikan sebagai parameter utama.

\section{Formulasi MMSM dengan pengering semprot skala laboratorium}

MMSM dibuat dengan mencampurkan maltodekstrin (MD) dan gum arab (GA) sebagai bahan penyalut menggunakan Homogenizer High Shear Rotary Silver-ston $L 4 R$ pada kecepatan maksimum. Kemudian ditambahkan MSM dan dibentuk emulsi melalui proses homogenisasi. Proses selanjutnya adalah dengan pengeringan emulsi menggunakan pengering semprot skala laboratorium BUCHI 190 Mini Spray Dryer dengan suhu inlet 140$180^{\circ} \mathrm{C}$, suhu outlet $80-100^{\circ} \mathrm{C}$ dengan kecepatan pompa skala 2. Tiga formula yang digunakan yaitu formula $A$ dengan perbandingan (MD:GA):MSM = (2:3): 1 mengacu pada hasil penelitian Fasikhatun (2010), formula B dengan perbandingan (MD:GA):MSM = (7:3):1 dan formula $\mathrm{C}$ dengan perbandingan (MD:GA):MSM = (7:3):0.8.

Kemudian dilakukan analisis karakteristik produk MMSM yaitu kadar air (SNI 01-2891) (BSN 1992), total karoten (PORIM p26 1988), kadar minyak tak terkapsulkan (Shahidi dan Wanasundara 1997), kelarutan (Fardiaz et al. 1992), serta warna bubuk dan larutan mikroenkapsulat MSM (Hutching 1999).

\section{Produksi mikroenkapsulat dengan pengering semprot skala pilot plant $(300 \mathrm{~mL} / \mathrm{menit})$}

Hasil formulasi pengering semprot skala laboratorium digunakan sebagai dasar produksi mikroenkapsulat dengan pengering semprot skala pilot plant. Spesifikasi pengering semprot skala pilot plant menggunakan suhu inlet $215^{\circ} \mathrm{C}$, suhu outlet $110^{\circ} \mathrm{C}$, tekanan pompa 4.5 bar, dan kecepatan cyclon $2500 \mathrm{~m}^{3} / \mathrm{jam}$. Percobaan pertama menggunakan formula optimal dari pengering semprot skala laboratorium dan reformulasi kembali dilakukan mengubah perbandingan penyalut : MSM adalah 1:0.3; $1: 0.4 ; 1: 0.5 ; 1: 0.6$. Total emulsi yang digunakan untuk memproduksi MMSM dengan alat ini sekitar 8-10 liter.

Pada tahap ini juga dilakukan karakterisasi MMSM antara lain analisis kadar air (SNI 01-2891) (BSN 1992), total karoten (PORIM p26 1988), kadar minyak tak terkapsulkan (Shahidi dan Wanasundara 1997), kelarutan (Fardiaz et al. 1992), flowability, serta warna bubuk dan larutan mikro-enkapsulat MSM (Hutching 1999).

\section{HASIL DAN PEMBAHASAN}

\section{Karakteristik minyak sawit merah}

Konsentrasi karoten pada MSM yang didapat berdasarkan hasil analisis adalah sebanyak 474.7138 $17.0692 \mathrm{mg}$ karoten $/ \mathrm{kg}$ minyak. Dari data ini juga didapati bahwa bilangan peroksida dari MSM sebesar $51.36 \pm 3.68 \mathrm{meq} / \mathrm{kg}$ sampel. Sementara untuk bilangan asam didapat sebesar $0.79 \pm 0.00 \mathrm{mg} \mathrm{NaOH} / \mathrm{g}$ minyak dan kadar asam lemak bebasnya sebesar $0.55 \pm 0.01 \%$. 
Berdasarkan SNI tahun 2006 tentang Refined Bleached Deodorized Olein disarankan bahwa kadar maksimum untuk bilangan asam lemak bebas adalah $0.1 \%$. Sedangkan nilai maksimal bilangan peroksida adalah 15 meg $\mathrm{O}_{2} / \mathrm{kg}$ minyak (Codex 2005). Hasil analisis bahan baku minyak sawit merah pada penelitian ini tidak memenuhi standar yang ada, hal ini disebabkan penyimpanan yang sudah terlalu lama setelah proses produksi minyak sawit merah yang dilakukan pada tahun 2013. Perbaikan proses produksi minyak sawit merah ini perlu dilakukan agar dapat menghasilkan minyak sawit merah yang sesuai standar dan memiliki kualitas baik. Total karoten dijadikan parameter utama dan dianggap masih memiliki standar kualitas yang baik.

\section{Formulasi produk MMSM dengan pengering semprot skala laboratorium}

Proses pembuatan MMSM ini dilakukan dengan cara pelarutan penyalut maltodekstrin dan gum arab dengan mengunakan air bersuhu sekitar $60^{\circ} \mathrm{C}$. Kemudian ditambahkan air sampai total solid didapatkan $30 \%$ dan diaduk sampai larut sempurna. Penambahan tween 80 kemudian dilakukan, lalu homogenisasi pertama dengan menggunakan homogenizer High Shear Rotary Silverson LAR pada kecepatan maksimal selama 5 menit. Pendinginan kemudian dilakukan untuk menjaga suhu larutan tidak terlalu tinggi. Homogenisasi kedua dilakukan pada kecepatan maksimum selama 10 menit dan penambahan minyak sawit merah secara perlahanlahan dengan tujuan penyalutan MSM yang lebih sempurna. Kemudian dikeringkan dengan pengering semprot dengan suhu inlet $140-180^{\circ} \mathrm{C}$, suhu outlet 80 $100^{\circ} \mathrm{C}$ dengan kecepatan pompa skala 2 (Gambar 1). Menurut Garti dan McClements (2012), saat melewati nozzle, akan terbentuk droplet dari emulsi yang akan mengalami kontak dengan udara panas pada chamber pengering semprot sehingga terjadi penguapan air pada droplet. Perbedaan tekanan uap menyebabkan air dapat menguap sehingga produk menjadi kering. Waktu kontak menentukan suhu akhir dari produk.

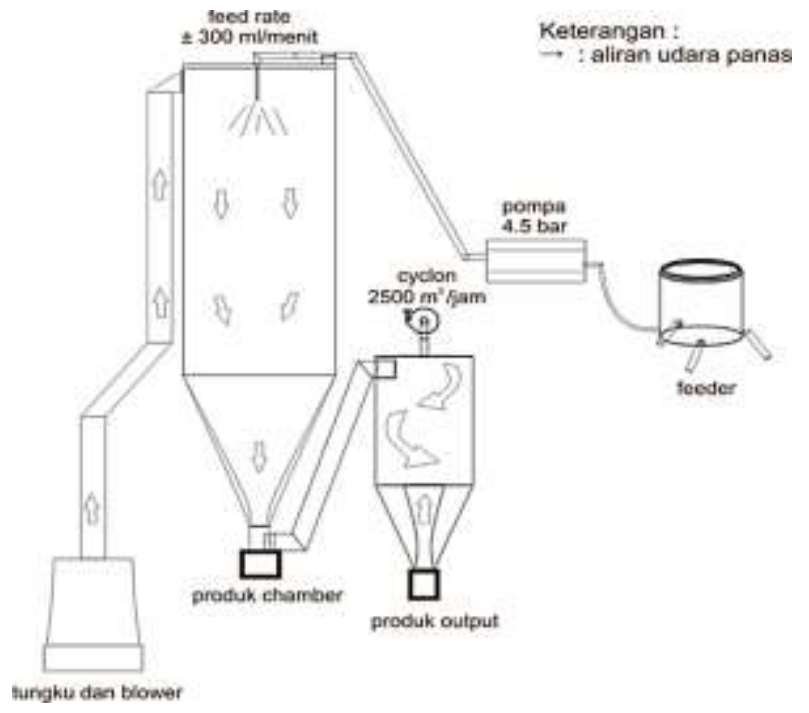

Gambar 1. Produksi mikroenkapsulat
Formulasi A merupakan hasil penelitian Fasikhatun (2010) ternyata tidak menghasilkan produk MMSM kering. Penambahan maltodekstrin sebagai bahan penyalut didasarkan penelitian Anwar (2002), pada konsentrasi $10-25 \%$, maltodekstrin menjadi penyalut lapis tipis tablet dengan hasil cukup memuaskan. Harga maltodekstrin juga cenderung lebih ekonomis ketimbang produk lain. Aspek ekonomi juga menjadi pertimbangan karena akan dilakukan peningkatan skala (Tabel 1). Formula B, penambahan maltodekstrin menghasilkan produk MMSM kering, untuk memperbaiki karakteristik powder dari MMSM formula $\mathrm{C}$ dilakukan pengurangan perbandingan penyalut:MSM 1:0.8. Formula ini optimal didapat dari pengering semprot skala laboratorium dan akan dilakukan peningkatan skala produksi.

Tabel 1. Hasil formulasi MMSM dengan buchi 190 mini spray

\begin{tabular}{|c|c|c|}
\hline $\begin{array}{c}\text { Formulasi } \\
\text { (MD:GA: } \\
\text { MSM) }\end{array}$ & Penyalut:MSM & Deskripsi Produk \\
\hline $\begin{array}{c}A \\
(20: 30): 100\end{array}$ & $(1: 2)$ & $\begin{array}{l}\text { Bubuk MMSM yang dihasilkan tidak } \\
\text { kering (berminyak) sehingga pada } \\
\text { formula selanjutnya (B) dilakukan } \\
\text { penambahan matodektrin yang dapat } \\
\text { berfungsi sebagai penyalut. }\end{array}$ \\
\hline $\begin{array}{c}\text { B } \\
(70: 30): 100\end{array}$ & $(1: 1)$ & $\begin{array}{l}\text { Bubuk MMSM cukup kering, akan } \\
\text { tetapi masih belum memiliki flow } \\
\text { ability yang cukup baik. Selanjutnya } \\
\text { (C) untuk mendapatkan karakteristik } \\
\text { bubuk yang baik dilakukan pengura- } \\
\text { ngan jumlah minyak hingga men- } \\
\text { capai rasio penyalut:MSM }=1: 0.8 \text {. }\end{array}$ \\
\hline $\begin{array}{c}C \\
(70: 30): 80\end{array}$ & $(1: 0.8)$ & $\begin{array}{l}\text { Bubuk MMSM kering dan cukup baik } \\
\text { sehingga dijadikan acuan sebagai } \\
\text { formula optimal dan digunakan untuk } \\
\text { percobaan dengan pengering sem- } \\
\text { prot skala pilot plant ( } 300 \mathrm{~mL} / \mathrm{menit} \text {. }\end{array}$ \\
\hline
\end{tabular}

\section{Minyak sawit merah dengan pengering semprot skala pilot plant $(300 \mathrm{~mL} / \mathrm{menit})$}

Pada peningkatan skala produksi memerlukan adanya penyesuaian alat maupun formula dari bahan yang akan dikeringkan (Scoot et al. 2007). Pengering semprot skala pilot plant memiliki spesifikasi yang berbeda dengan pengering semprot jenis Buchi 190 mini spray dryer yang ada pada pilot plant PAU IPB.

Pada produksi ini, digunakan parameter suhu inlet $215^{\circ} \mathrm{C}$, suhu outlet $110^{\circ} \mathrm{C}$, tekanan pompa $4.5 \mathrm{bar}$, dan kecepatan cyclon $2500 \mathrm{~m}^{3} / \mathrm{jam}$. Sumber panas berasal dari tungku hasil pembakaran gas elpiji sebagai sumber energinya. Udara panas (tanda panah pada Gambar 2) dibawa oleh blower menuju chamber. Udara inlet pada alat ini rata-rata memiliki RH sekitar 2. Pada chamber udara panas melakukan kontak dengan sampel emulsi yang dimasukan melalui feeder dengan kekuaran pompa 4.5 bar. Produk kering ditarik oleh cyclon dengan kekuatan $2500 \mathrm{~m}^{3}$ volume udara per jam. Pengering semprot memiliki kapasitas sekitar $100 \mathrm{~L}$ dan dapat digunakan untuk melakukan proses produksi secara continue. Spesifikasi pengering semprot skala pilot plant (300 mL/menit) berbeda dengan Buchi 190 mini spray dryer yang digunakan pada trial sebelumnya dan dapat dilihat secara lengkap pada Tabel 2. 


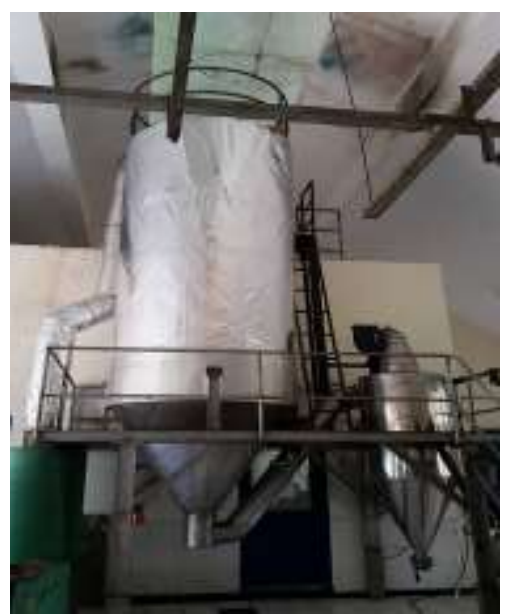

Gambar 2. Penampakan fisik skema pengering semprot skala pilot plant

Tabel 2. Spesifikasi pengering semprot skala laboratorium dan skala pilot plant

\begin{tabular}{lll}
\hline \multicolumn{1}{c}{ Parameter } & \multicolumn{1}{c}{$\begin{array}{c}\text { Pengering Skala Lab } \\
\text { (Buchi 190 Mini Spray } \\
\text { Dryer) }\end{array}$} & $\begin{array}{c}\text { Pengering } \\
\text { Semprot Skala } \\
\text { Pilot Plant }\end{array}$ \\
\hline Diameter chamber $(\mathrm{m})$ & 0.1 & 1.55 \\
Tinggi chamber $(\mathrm{m})$ & 0.8 & 5.1 \\
Kapasitas alat & $0.1-5$ liter & 100 liter \\
Suhu inlet ${ }^{\circ} \mathrm{C}$ & $140-180$ & 215 \\
Suhu outlet ${ }^{\circ} \mathrm{C}$ & $80-100$ & 110 \\
Laju alir & $8.3(\mathrm{~mL} /$ menit) & 300 (mL/menit) \\
Tekanan pompa & 2 bar & 4.5 bar \\
Jenis nozzle & two-fluid Nozzle & Pressure Nozzle \\
Aliran udara panas & atomization & Atomisation \\
Kekuatan cyclon & Cocurrent & Cocurrent \\
(m3 udara/jam) & 600 & 2500 \\
Material chamber dan & & Kaca \\
cyclone & & stainless steel \\
Volume emulsi sampel & 500 & dengan insulator \\
(mL) & & $80,000-10,000$ \\
\hline
\end{tabular}

Formula $\mathrm{C}$ hasil percobaan dengan pengering semprot Buchi 190 mini spray dryer digunakan sebagai dasar percobaan menggunakan pengering semprot skala pilot plant. Peningkatan volume basis emulsi menjadi 8$10 \mathrm{~L}$ emulsi untuk sekali produksi. Dilakukan perubahan proses homogenisasi I menjadi 25 menit dan homogenisasi II menjadi 45 menit, didapatkan berdasarkan hasil percobaan. Penambahan waktu homogenisasi dilakukan karena mengingkatnya jumlah volume emulsi yang dibuat menjadi $10 \mathrm{~L}$ setiap satu sampel formula. Peningkatan waktu homogenisasi perlu dilakukan bila ada penambahan basis emulsi (Ilma 2014).

Formula optimum dengan pengering semprot skala laboratorium menunjukan hasil kurang memuaskan saat diproduksi skala pilot plant. Chamber pengering semprot basah dengan minyak dan tidak ada produk MMSM output produk. Penyesuaian formula dilakukan untuk mendapatkan bubuk mikroenkapsulat yang baik. Penampakan fisik hasil uji coba produksi MMSM dengan pengering semprot skala pilot plant menggunakan formula skala laboratorium dan empat formula yang sudah disesuaikan dengan menurunkan proporsi minyak dalam formula (Tabel 3). Beberapa perbedaan spesifikasi pengering semprot menjadi penyebab tidak keringnya produk MMSM saat percobaan. Pengering semprot skala pilot plant ini menggunakan Pressure Nozzle Atomisation yang berbeda dengan pengering semprot skala laboratorium Buchi 190 mini spray dryer yaitu two-fluid Nozzle atomization. Tekanan tinggi saat menginjeksi sampel dibutuhkan untuk mengasilkan karakter pengabutan yang baik (Tamaki dan Shimizu 2002).

Tabel 3. Formulasi dan penampakan fisik hasil produksi dengan pengering semprot skala pilot plant

\begin{tabular}{|c|c|c|}
\hline $\begin{array}{l}\text { Formulasi } \\
\text { (MD:GA: } \\
\text { MSM) }\end{array}$ & $\begin{array}{c}\text { Penyalut: } \\
\text { MSM }\end{array}$ & Keterangan \\
\hline $\begin{array}{c}\text { Skala lab } \\
(70: 30): 80\end{array}$ & $(1: 0.8)$ & $\begin{array}{l}\text { Perbedaan karakterisitik pengkabutan } \\
\text { dengan meningkatnya laju alir dan lebih } \\
\text { besarnya ukuran droplet yang dihasilkan } \\
\text { menyebabkan tidak keringnya produk } \\
\text { formula optimum. Selanjutnya dilakukan } \\
\text { pengurangan penambahan MSM. }\end{array}$ \\
\hline $\begin{array}{c}1 \\
(70 \cdot 30) \cdot 60\end{array}$ & $(1: 0.6)$ & Peningkatan total minyak yang ditamba- \\
\hline $\begin{array}{c}\text { II } \\
(70: 30): 50\end{array}$ & $(1: 0.5)$ & $\begin{array}{l}\text { nkan berpengarun menıngkatkan total } \\
\text { karoten yang terkandung dalam MMSM. } \\
\text { Tetapi peningkatan minyak juga cenderung }\end{array}$ \\
\hline $\begin{array}{c}\text { III } \\
(70: 30): 40\end{array}$ & $(1: 0.4)$ & $\begin{array}{l}\text { meningkatan kadar minyak tidak tersalut- } \\
\text { kan dari produk yang berdampak pada } \\
\text { meningkatnya kohesifitas dari MMSM dan }\end{array}$ \\
\hline $\begin{array}{c}\text { IV } \\
(70: 30): 30\end{array}$ & $(1: 0.3)$ & $\begin{array}{l}\text { meningkatnya sudut repose sehingga me- } \\
\text { nurunnya kemampuan flowability dari } \\
\text { produk. Peningkatan total minyak juga } \\
\text { memberikan korelasi positif terhadap nilai b } \\
\text { atau warna kuning tetapi memberikan } \\
\text { korelasi negatif pada tingkat kecerahan } \\
\text { atau nilai L. }\end{array}$ \\
\hline
\end{tabular}

Sampel dipompa dengan tekanan tinggi untuk melalui lubang pada nozzle sehingga memecah sampel menjadi droplet halus. Untuk mengurangi ukuran partikel pada laju alir konstan, penggantian nozzle dengan lubang kecil perlu dilakukan. Semakin kecil lubang nozzle, maka tekanan pompa yang semakin besar juga dibutuhkan untuk menghasilkan laju alir bahan yang sama. Tekanan pompa 4.5 bar menghasilkan laju alir 300 (mL/menit). Pressure nozzle atomisation cenderung menghasilkan droplet lebih besar. Two-fluid Nozzle atomization dapat menghasilkan droplet ukuran 10-50 $\mu \mathrm{m}$ lebih kecil bila dibandingkan Pressure Nozzle Atomisation yang hanya menghasilkan droplet diameter $10^{2}-10^{3} \mu \mathrm{m}$ (Hino et al. 2000, Dharshini et al. 2008). Ukuran diameter droplet kecil meng-hasilkan proses pengeringan yang lebih baik (Huang et al. 2006).

Selain ukuran droplet yang lebih besar, bila dibandingkan pengering semprot skala laboratorium Buchi 190 mini spray dryer, walaupun dengan komposisi formula sama, pengering semprot skala pilot plant memiliki laju aliran bahan lebih cepat. Hal ini menyebabkan lebih banyaknya emulsi yang diseprotkan ke dalam chamber per satuan waktu. Dalam proses pengeringan dibutuhkan energi dalam bentuk kalor untuk dapat mengeringkan produk dengan menguapkan air sehingga pada pengering semprot membutuhkan kalor lebih banyak untuk mencapai laju pengeringan yang sama saat mengeringkan produk dengan pengering semprot Buchi 190 mini spray dryer. Tinggi chamber $5.1 \mathrm{~m}$ memberi waktu kontak udara panas lebih lama terhadap produk, tetapi tidak keringnya produk MMSM ini dikarenakan laju alir terlalu cepat dan ukuran droplet besar. Peningkatan suhu pengeringan dapat meningkatkan laju pengeringan produk tetapi berpotensi merubah 
komposisi kimia atau pun fisik dari produk yang dikeringkan (Fernández-Péreza et al. 2004, Dharshini et al. 2008) dalam hal ini kadungan karoten dalam sampel. Juga menurut Kajiyama dan Park (2010) dengan meningkatnya suhu udara pengering, efisiensi panas akan berkurang sehingga berdampak pada peningkatan konsumsi energi.

\section{Karakterisasi produk mikroenkapsulat minyak sawit merah skala pilot plant}

Karakterisasi produk mikroenkapsulat MSM dilakukan hanya untuk produk yang dikoleksi dari bagian cyclon menggunakan formula yang telah disesuaikan (formula I, II, III dan IV) dibandingkan dengan formula produk yang dihasilkan dari skala laboratorium.

\section{Kadar minyak tidak terenkapsulkan (KMTT)}

Pada proses mikroenkapsulasi, tidak semua bahan inti dapat tersalutkan sempurna. KMTT merupakan banyaknya minyak (bahan inti) yang tidak terikat sempurna pada matriks penyalut atau yang menempel pada luar dinding penyalut. Hal ini menyebabkan tidak terlindunginya komponen aktif dari bahan inti minyak yaitu karoten terhadap oksidasi sehingga mempercepat penurunan total karoten pada saat penyimpanan. KMTT menyebabkan adanya minyak yang menempel pada alat pengering semprot sehingga menyebabkan rendahnya rendemen proses.

Nilai KMTT pada produk untuk pengering semprot skala pilot plant yaitu 7.90-14.66\%, untuk skala laboratorium adalah $23.19 \%$. Bila dibandingkan data Fasikhatun (2010) hasil lebih baik mendapatkan nilai KMTT yang mencapai hingga 32.24-56.34\% (Tabel 4).

Tabel 4. Kadar minyak tidak tersalutkan dan efisiensi mikroenkapsulasi produk MMSM

\begin{tabular}{ccc}
\hline $\begin{array}{c}\text { Formula } \\
\text { (Penyalut: } \\
\text { MSM) }\end{array}$ & $\begin{array}{c}\text { Kadar Minyak tak } \\
\text { Terenkapsulkan (\%) }\end{array}$ & $\begin{array}{c}\text { Efisiensi } \\
\text { Mikroenkapsulasi (\%) }\end{array}$ \\
\hline I (1:0.3) & $7.9029^{\mathrm{a}}$ & $65.36 \pm 0.91$ \\
II $(1: 0.4)$ & $8.4379^{\mathrm{b}}$ & $70.15 \pm 0.28$ \\
III $(1: 0.5)$ & $15.4920^{\mathrm{e}}$ & $53.06 \pm 0.20$ \\
IV $(1: 0.6)$ & $14.6609^{\mathrm{d}}$ & $60.54 \pm 1.01$ \\
Lab (1:0.8) & $23.1918^{\mathrm{h}}$ & $47.38 \pm 0.44$ \\
\hline
\end{tabular}

Keterangan: Huruf yang sama di belakang angka pada baris yang sama menunjukkan tidak berbeda nyata $(p>0.05)$

Nilai kadar minyak tidak tersalutkan mempengaruhi efisiensi mikroenkapsulasi. Beberapa faktor yang mempengaruhi efisiensi mikroenkapsulasi adalah total padatan, suhu inlet, dan pengering semprot itu sendiri. Nilai efisiensi mikroenkapsulasi didapatkan dari perbandingan antara banyaknya total minyak yang tersalutkan dengan total minyak keseluruhan pada produk dikalikan dengan $100 \%$. Pada penelitian ini banyaknya total minyak keseluruhan dianggap sebagai banyaknya minyak yang ditambahkan pada formula mikroenkapsulat. Pada sampel nilai efisiensi mikroenkapsulasi berkisar antara 53.06-70.15\%.

Nilai efisiensi mikroenkapsulasi diduga sangat dipengaruhi oleh faktor homogenisasi dan kurang sempurnanya proses mikroenkapsulasi. Pada proses pembuatan emulsi, homogenisasi dilakakukan dengan menggunakan alat Homogenizer High Shear Rotary Silverston $L 4 R$ pada kecepatan maksimum. Peninjauan ulang proses homogenisasi dirasakan dapat meningkatkan efisiensi mikroenkapsulat. Pada saat pengingkatan skala, penggunaan homogenizer sistem continues seperti double impact homogenizer diduga akan memberikan hasil yang lebih baik. Menurut Ilma (2014), peningkatan volume emulsi (penambahan minyak) sebaiknya diiringi dengan penambahan waktu homogenisasi untuk mendapatkan kadar minyak tidak terkapsulkan yang rendah.

\section{Kadar air}

Kadar air produk mikroenkapsulat yang didapat berkisar antara 0.45-1.73\% (Tabel 5) sehingga memenuhi standar yang ditentukan oleh SNI 2006 (BSN 2006) tentang susu bubuk yaitu dibawah $5 \%$. Hasil ini juga mendekati hasil Adamiec dan Kalemba (2006) yang meneliti tentang proses pengeringan semprot pada minyak esensial yang mendapatkan kadar air sekitar 1.704.16\%. Penelitian Fasikhatun (2010) dengan menggunakan pengering semprot skala laboratorium juga menghasilkan mikroenkapsulat dengan kadar air sekitar 0.62$2.92 \%(\mathrm{~b} / \mathrm{k})$ sehingga penggunaan pengering semprot skala pilot plant ini tidak berpengaruh pada perubahan karakteristik kadar air mikroenkapsulat yang dihasilkan.

Tabel 5. Kadar air mikroenkapsulat minyak sawit merah produk output

\begin{tabular}{cc}
\hline Formula (Penyalut:MSM) & Kadar Air (\%bb) \\
\hline I $(1: 0.3)$ & $1.73 \pm 0.02$ \\
II $(1: 0.4)$ & $0.84 \pm 0.02$ \\
III $(1: 0.5)$ & $0.45 \pm 0.01$ \\
IV $(1: 0.6)$ & $0.78 \pm 0.01$ \\
Lab $(1: 0.8)$ & $0.54 \pm 0.16$ \\
\hline
\end{tabular}

Menurut Risch (1995) kadar air produk hasil pengeringan dengan pengering semprot berkisar antara 2$6 \%$. Berdasarkan hasil penelitian Hadi (2009), pengering semprot dapat menghasilkan produk mikroenkapsulat minyak sawit merah dengan kadar air terendah dibandingkan dengan alat pengering lain seperti oven, tray drier, drum drier, TDM box, dan TDM silinder.

\section{Kelarutan}

Air merupakan pelarut yang digunakan pada produk pangan sehingga kelarutan mikroenkapsulat dalam air merupakan faktor yang sangat diperhatikan. Kelarutan produk dari setiap sampel dapat dilihat pada Tabel 6.

Tabel 6. Kelarutan mikroenkapsulat minyak sawit merah produk

\begin{tabular}{cc}
\hline Formula (Penyalut:MSM) & Kelarutan (\%) \\
\hline I (1:0.3) & $96.11^{\mathrm{bc}}$ \\
II $(1: 0.4)$ & $93.96^{\mathrm{a}}$ \\
III $(1: 0.5)$ & $95.97^{\mathrm{bc}}$ \\
IV $(1: 0.6)$ & $95.74^{\mathrm{b}}$ \\
Lab $(1: 0.8)$ & $97.06^{\mathrm{c}}$ \\
\hline Keterangan:
\end{tabular}

Keterangan: Huruf yang sama di belakang angka pada baris yang sama menunjukkan tidak berbeda nyata $(p>0,05)$

Berdasarkan hasil analisis, kelarutan yang didapat antara $93.96-97.06 \%$. Hal ini menunjukan peningkatan 
kelarutan pada penelitian Fasikhatun (2010) yaitu antara 60.30-78.87\%. Peningkatan komposisi maltodekstrin sebagai penyalut meningkatkan kelarutan karena sifatnya yang mudah larut (Westing dan Rennecius 1988). Tween 80 berfungsi sebagai emulsifier membantu pembentukan emulsi minyak dengan air yang juga meningkatkan kelarutan. Hasil uji lanjut duncan pada taraf nyata 5\% menunjukan sedikit perbedaan signifikan terhadap nilai kelarutan. Sedangkan peningkatan MSM pada formula tidak menurunkan nilai kelarutan secara signifikan.

\section{Total karoten}

Karoten dalam MSM memiliki sifat fungsional sebagai provitamin A dan mengandung pigmen berwarna kuning, jingga, atau merah jingga (Winarno 2004). Sifatnya yang peka terhadap oksidasi, autooksidasi, dan cahaya menyebabkan karoten memerlukan perlakuan khusus untuk mencegah rusaknya karoten selama penyimpanan dengan proses mikroenkapsulasi.

Nilai karoten dan retensi produk mikroenkapsulat menggunakan pengering semprot skala pilot plant berkisar 56.8297-118.5540 ppm, skala laboratorium didapat 168.0914 ppm (Tabel 7). Berdasarkan uji Duncan kenaikan jumlah minyak yang ditambahkan cenderung untuk meningkatkan total karoten produk MMSM secara signifikan. Nilai total karoten lebih besar bila dibandingkan dengan Fasikhatun (2010) yang hanya mendapatkan nilai sekitar 31.46-82.63 ppm.

Retensi karoten merupakan perbandingan antara jumlah karoten yang seharusnya ada pada produk mikroenkapsulat berdasarkan perhitungan teori dengan total karoten nyata yang ada pada produk berdasarkan hasil analisis. Retensi karoten yang didapat berkisar antara 51.79-79.26\%. Hasil ini lebih baik dari penelitian Yudha (2008) tentang optimasi formula mikroenkapsulat minya sawit merah menggunakan thin layer drying yang mendapatkan hasil retensi total karoten pada kisaran 33.33-70.75\%. Simanjuntak (2007) juga meneliti tentang mikroenkapsulat minyak sawit merah dan mendapatkan hasil retensi total karoten pada kisaran 38.06-97.53\%. Perbaikan rentensi karoten dapat terjadi bila adanya peningkatan suhu pengering karena dengan tingginya suhu maka pembentukan film pada permukaan partikel lebih cepat sehingga dapat menjadi lapisan pelindung yang mencegah migrasi bahan inti (Rascon et al. 2011).

Tabel 7. Total karoten dan rentensi karoten mikroenkapsulat minyak sawit merah

\begin{tabular}{ccc}
\hline $\begin{array}{c}\text { Formula } \\
\text { (Penyalut:MSM) }\end{array}$ & $\begin{array}{c}\text { Total Karoten }(\mathbf{m g} / \mathbf{k g} \\
\text { Bubuk }(\mathbf{p p m}))\end{array}$ & $\begin{array}{c}\text { Retensi } \\
\text { Karoten }(\%)\end{array}$ \\
\hline I $(1: 0.3)$ & $56.8297^{\mathrm{a}}$ & $51.79 \pm 2.92$ \\
II $(1: 0.4)$ & $91.7202^{\mathrm{b}}$ & $67.46 \pm 1.82$ \\
III $(1: 0.5)$ & $88.4773^{\mathrm{b}}$ & $55.74 \pm 0.48$ \\
IV $(1: 0.6)$ & $118.5540^{\mathrm{c}}$ & $66.35 \pm 0.48$ \\
Lab $(1: 0.8)$ & $168.0914^{\mathrm{d}}$ & $79.26 \pm 0.26$
\end{tabular}

Keterangan: Huruf yang sama di belakang angka pada baris yang sama menunjukkan tidak berbeda nyata $(p>0.05)$

\section{Warna}

Produk hasil mikroenkapsulat menghasilkan warna kuning yang berbeda-beda setiap perlakuan dan sampel.
Setiap sampel memiliki kisaran nilai b positif antara 52.72-66.06 untuk pengering semprot skala pilot plant dan 76.48 untuk skala laboratorium. Hal ini menunjukan sampel memiliki warna kuning dengan intensitas warna yang berbeda. Peningkatan jumlah konsentrasi minyak yang ditambahkan pada formula memberikan korelasi positif terhadap intensitas warna kuning pada produk mikroenkapsulat. Uji lanjut Duncan dilakukan pada taraf nyata $5 \%$ dan menunjukan bahwa peningkatan kandungan minyak pada tiap formula memberikan dampak yang signifikan pada peningkatan nilai positif $b$.

Nilai L, peningkatan konsentrasi minyak yang ditambahkan memberikan korelasi negatif. Nilai kecerahan cenderung turun seiring dengan pertambahan jumlah minyak. Tingginya nilai $L$ pada formula I disebabkan karena komposisi penyalut lebih banyak sehingga memberikan intensitas warna putih lebih tinggi dikarena maltodekstrin cenderung berwarna putih. Nilai L yang didapat pengering semprot skala pilot plant adalah 84.20-82.63 sedangkan untuk skala laboratorim 82.59.

Bila dibandingkan antara kedua parameter, peningkatan konsentrasi minyak menyebabkan peningkatan intensitas warna kuning (nilai positif b) dan penurunan tingkat kecerahan dari sampel (nilai L). Nilai lab sampel secara lengkap dapat dilihat pada Tabel 8.

Tabel 8. Nilai Lab dari sampel mikroenkapsulat minyak sawit merah

\begin{tabular}{cccc}
\hline $\begin{array}{c}\text { Formula } \\
\text { (Penyalut:MSM) }\end{array}$ & a & B & L \\
\hline I $(1: 0.3)$ & -4.11 & $52.72^{\mathrm{a}}$ & $84.20^{\mathrm{c}}$ \\
II $(1: 0.4)$ & -3.83 & $58.37^{\mathrm{b}}$ & $83^{\mathrm{b}}$ \\
III $(1: 0.5)$ & -3.04 & $62.1^{\mathrm{c}}$ & $82.63^{\mathrm{a}}$ \\
IV $(1: 0.6)$ & -2.98 & $66.06^{\mathrm{d}}$ & $83.21^{\mathrm{b}}$ \\
Lab (1:0.8) & 1.04 & $76.48^{\mathrm{e}}$ & $82.59^{\mathrm{a}}$ \\
\hline
\end{tabular}

Keterangan: Huruf dan angka romawi yang sama di belakang angka pada baris yang sama menunjukkan tidak berbeda nyata $(p>0.05)$

\section{Sudut repose}

Sudut repose merupakan salah satu parameter yang dapat menggambarkan kemampuan mengalir suatu produk bubuk (Flowability). Berdasarkan Walton dan Mumford (1999) karakteristik suatu produk bubuk berdasarkan sudut repose dapat dibagi menjadi 3 yaitu (1) freeflowing dengan sudut repose berkisar $17-55^{\circ}$ (ratarata $30^{\circ}$; (2) semi-freeflowing dengan sudut repose berkisar $33-64^{\circ}$ (rata-rata $44^{\circ}$ ); (3) Cohesive dengan sudut repose berkisar $35-90^{\circ}$ (rata-rata $57^{\circ}$ ). Tipe produk bubuk dari sifat flowability dapat dikaitkan dengan interaksi produk dengan peralatan produksi dalam proses produksi terutama dalam perpindahan atau pergerakan produk (Prescott dan Barnum 2000). Menurut Fitzpatrick dan Ahrne (2005) dan Walton dan Mumford (1999), beberapa faktor yang mempengaruhi nilai kemudahan mengalir suatu produk adalah bentuk dan ukuran partikel, interaksi permukaan, kadar air, penggumpalan, kondisi penyimpanan, penyebaran ukuran partikel, dan nilai higroskopis dari suatu partikel.

Dari hasil penelitian menunjukan bahwa sampel memiliki sudut repose diantara 36.54 sampai 43.05. Bila didasarkan pada klasifikasi, maka sampel termasuk 
dalam jenis semi-freeflowing product. Semi-freeflowing produk bubuk cenderung memiliki bentuk partikel yang lebih tidak beraturan dibandingkan dengan freeflowing produk (Walton dan Mumford 1999) sehingga pergerakan aliran produk lebih terbatas. Pada produk mikroenkapsulat ini, nilai KMTT dapat menyebabkan meningkatnya nilai sudut repose dari produk karena minyak dapat meningkatkan sifat kohesif dari produk. Hal ini menjadi penyebab sering menggumpalnya produk hasil mikroenkapsulat dan mengurangi laju alir dari produk. Nilai sudut repose dari produk dapat dikurangi dengan mengurangi nilai KMTT. Menurut Priyanto et al. (2005) nilai sudut repose dari tepung kacang hijau adalah $37.63^{\circ}$. Produk mikroenkapsulat ini memiliki sudut repose yang lebih besar dari tepung kacang hijau.

\section{KESIMPULAN}

Peningkatan skala produksi dari skala laboratorium ke skala pilot memerlukan penyesuain formula sehingga dihasilkan produk MMSM yang kering. Penyesuaian perbandingan kandungan minyak terhadap bahan penyalut yang ditambahkan menjadi alternatif yang dapat dilakukan. Ukuran droplet yang dipengaruhi oleh laju alir produk dan jenis atomizer merupakan faktor penentu yang harus diperhatikan dalam peningkatan skala produksi mikroenkapsulat minyak sawit merah dari skala laboratorium ke skala pilot plant. Produksi skala pilot menggunakan formula dengan rasio perbandingan penyalut : MSM adalah 1:0.3 hingga 1:0.6 menghasilkan MMSM kering yang baik dengan karakteristik produk bubuk total karoten (56.8297-118.5540 ppm), kadar air (0.45-1.73\%), kelarutan (93.96-97.06\%), dan kadar minyak tak tersalutkan (7.90-14.66\%).

\section{UCAPAN TERIMA KASIH}

Ucapan terima kasih kepada Program RISPROLPDP Kementerian Keuangan RI atas bantuan pendanaan penelitian ini pada tahun 2014, serta kepada Prof. Dr. Nuri Andarwulan (SEAFAST Center IPB) dan PT Salim Ivomas Pratama atas dukungan yang diberikan demi kelancaran penelitian ini.

\section{DAFTAR PUSTAKA}

Adamiec J, Kalemba D. 2006. Analysis of microencapsulation ability of essential oils during spray drying. Dry Technol 24(9): 1127-1132. DOI: 10.1080/07373930600778288.

Anwar E. 2002. Pemanfaatan maltodekstrin dari pati singkong sebagai bahan penyalut lapis tipis tablet. $\mathbf{J}$ Makara 6(1): 50-54. DOI: 10.7454/mss.v6i1.36.

[AOCS] American Oil Chemists Society. 1989. Offcial Methods and Recommended Practices of The American Oil Chemists Society.
[AOCS] American Oil Chemists Society. 1997. Offcial Methods and Recommended Practices of The American Oil Chemists Society.

[AOCS] American Oil Chemists Society. 2003. Offcial Methods and Recommended Practices of The American Oil Chemists Society.

[BSN] Badan Standarisasi Nasional. 1992. SNI 01-28911992: Cara Uji Makanan dan Minuman. Jakarta: BSN.

[BSN] Badan Standarisasi Nasional. 2006. SNI 01-00182006: Refined Bleached Deodorized Palm Olein (RBD Palm Olein). Jakarta: BSN.

Codex Alimentarius. 2005. Codex Stan-210: Named Vegetables Oils. Codex.

Dharshini S, Victor PS, Bensely A, Godson AL. 2008. Heat and Mass Transfer Study in the Spray Drying of Tomato Juice. 5th WSEAS Int. Conf. on Heat and Mass transfer (HMT'08), Acapulco, Mexico, January 25-27. ISSN: 1790-2769. ISBN: 978-960-6766-31-2.

[DITJENBUN] Direktorat Jendral Perkebunan. 2014. Produksi komoditas tanaman perkebunan angka estimasi tahun 2013. http://ditjenbun.pertanian. go.id/statis-36-produksi.html. [20 Januari 2015].

Fardiaz D, Andarwulan N, Wijaya H, Puspitasari NL. 1992. Petunjuk Laboratorium Teknik Analisis Sifat Kimia dan Fungsional Komponen Pangan. Bogor: PAU Pangan dan Gizi, Institut Pertanian Bogor.

Fasikhatun T. 2010. Pengaruh Konsentrasi Maltodekstrin dan Gum Arab Terhadap Karakteristik Mikroenkapsulat Minyak Sawit Merah dengan Metode Spray Drying. [Skripsi]. Bogor: Fakultas Teknologi Pertanian, Institut Pertanian Bogor.

Fernández-Péreza V, Tapiadorb J, Martínc A, Luque de Castro MD. 2004. Optimization of the drying step for preparing a new commercial powdered soup. Innovative Food Sci Emerg Technol 5: 361-368. DOI: 10.1016/j.ifset.2004.05.001.

Fitzpatrick JJ, Ahrne L. 2005. Food powder handling and processing: Industry problems, knowledge barriers and research opportunities. Chem Eng Proc 44: 209214. DOI: $10.1016 /$ j.cep.2004.03.014.

Garti N, McClements DJ. 2012. Encapsulation Technologies and Delivery Systems for Food Ingredients and Nutraceuticals. Woodhead Publishing, Philladelphia. ISBN: 978-0-85709-124-6. DOI: 10.1533/ 9780857095909.

Hadi S. 2009. Kajian Optimasi Produksi Mikroenkapsulat Minyak Sawit Merah. [Skripsi]. Bogor: Fakultas Teknologi Pertanian, Institut Pertanian Bogor.

Hama I, Ohbu K. 2002. New Technology and Development on the Use of Palm Oil in Oleo-chemical Industries. Proceedings of Agriculture Conference. Indonesian Oil Palm research Institute (IOPRI): Enhancing Oil Palm Industry Development through Environmentally Friendly Technology.

Hino T, Shimabayashi S, Ohnishi N, Fujisaki M, Mori H, Watanabe O, Kawashima K, Nagao K. 2000. Development of a new type nozzle and spray dryer 
for induspercobaan production of fine powders. Eur J Pharm Biopharm 49: 79-85. DOI: 10.1016/S09396411(99)00060-0.

Huang LX, Kurichi K, Mujumdar AS. 2006. A comparative study of a spray dryer with rotary disc atomizer and pressure nozzle using computational fluid dynamic simulations. Chem Eng Proces 45: 461-470. DOI: 10.1016/j.cep.2005.11.004.

Hutching JB. 1999. Food Color and Appearance. Blackie Academic \& Professional, London.

Ilma AN. 2014. Teknik Homogenisasi dan Peningkatan Skala Mikroenkapsulat Minyak Sawit. [Skripsi]. Bogor: Fakultas Teknologi Pertanian, Institut Pertanian Bogor.

Kajiyama T, Park KJ. 2010. Influence of air parameters on spray drying energy consumption. Revista Brasileira de Produtos Agroindustriais, Campina Grande 12(1): 45-54. DOI: 10.15871/15178595/rbpa.v12n1p45-54.

[PORIM] Palm Oil Research Institute of Malaysia. 1988. PORIM Test Methods. Kuala Lumpur.

Prescott JK, Barnum RA. 2000. On powder flowability. Pharm. Technol 60-84.

Priyanto G, Sari G, Hamzah B. 2005. Profil dan laju perubahan mutu tepung kecambah kacang hijau selama penyimpanan. J Agb Industri Pertanian 7(3): 347-359.

Rascon MP, Beristain CL, Garcia HS, Salgado MA. 2011. Carotenoid retention and storage stability of spraydried encapsulated paprika oleoresin using gum Arabic and Soy protein isolate as wall materials. J Food Sci Tech 4: 549-557. DOI: 10.1016/j.lwt. 2010.08.021.

Risch SJ. 1995. Review of Patent for Encapsulation and Controlled Release of Food Ingredients. Risch SJ, Reineccius GA, Editor. Encapsulation and Controlled Release of Food Ingredients. American Chemical Society, Washington DC. Chapter 18. Pp. 197-203. DOI: 10.1021/bk-1995-0590.ch018.

Scoot DD, TJ Boser, McGlynn WG. 2007. Scaling up your food process. Food Technology Fact Sheet. http://www.fapc.okstate.scaleup. [20 Januari 2015].
Shahidi F, Wanasundara PK. 1997. Extraction and analysis of lipids. Akoh CC, Min DB, editor. Food Lipids, Chemistry Nutrition and Biotechnology $2^{\text {nd }}$ Edition. New York: Marcel Dekker Inc.

Simanjuntak M. 2007. Optimasi Formula Mikroenkapsulat Minyak Sawit Merah Menggunakan Maltodekstrin, Gelatin dan Carboxymethyl Cellulose dengan Proses Thin Layer Drying. [Skripsi]. Bogor (ID): Institut Pertanian Bogor.

Srihari E, Lingganingrum FS, Hervita R, S Wijaya H. 2010. Pengaruh Penambahan Maltodekstrin pada Pembuatan Santan Kelapa Bubuk. Seminar Rekayasa Kimia dan Proses, 4-5 Agustus, Semarang, Indonesia. Semarang (ID): Universitas Diponegoro. ISSN: 1411-4216.

Sumarna D. 2006. Proses degumming CPO (Crude Palm Oil) menggunakan membran ultrafiltrasi. J Teknol Pertanian 2(1): 24-30.

Tamaki N, Shimizu M. 2002. Enhancement of atomization of high-viscous liquid jet by pressure atomized nozzle. Zaragoza. ILASS-Europe. DOI: 10.1299/jsmecs.2002.40.167.

Walton DE, Mumford CJ. 1999. Spray Dried ProductsCharacterization of Particle Morphology. Trans IchemE 77. DOI: 10.1205/026387699525846.

Westing LL, Rennecius F. 1988. Shelf life of Storage Oil : Effect of Encapsulation by Spray drying, Extrusion, and Molecular Inclusion. In Flavor Encapsulation. Risch SJ, Rennecius GA, editor. ACS Symposium Series 370, American Chemical Society, Washington DC. DOI: 10.1021/bk-1988-0370.ch012.

Winarno FG. 2004. Kimia Pangan dan Gizi. PT. Gedia, Jakarta.

Yudha KB. 2008. Optimasi Formula Mikroenkapsulat Minyak Sawit Merah Menggunakan Pektin, Gelatin, dan Maltodekstrin Melalui Proses Thin Layer Drying. [Skripsi]. Bogor: Fakultas Teknologi Pertanian, Institut Pertanian Bogor.

JMP-03-18-11-Naskah diterima untuk ditelaah pada 04 Maret 2018. Revisi makalah disetujui untuk dipublikasi pada 08 Januari 2019. Versi Online: http://journal.ipb.ac.id/index.php/jmpi 